Article received on $1^{\text {st }}$ April 2015

Article accepted on $12^{\text {th }}$ May 2015

UDC: $025.173(497.11)$

$027.7(497.11)$

\author{
Romana Ribić* \\ University of Arts in Belgrade \\ Faculty of Music \\ Library
}

\title{
THE STRUCTURE, CONTENTS, AND SIGNIFICANCE OF PERIODICALS IN THE HOLDINGS OF THE LIBRARY OF THE FACULTY OF MUSIC IN BELGRADE
}

\begin{abstract}
This paper presents the structure, contents, and significance of Yugoslav, Serbian, and foreign journals on music and other topics (literature, pedagogy, library science and IT, culture, art in general) in the holdings of the Library of the Faculty of Music in Belgrade. This collection constitutes a large section of the overall holdings of the Library. The paper discusses current, less current, and archived periodicals and focuses on the most frequently used Serbian and foreign, mainly scholarly, music journals, with their impact factor (IF) measured in the last two years. Also, the paper details the Library's acquisition policy, processing treatment of the journals (in its book inventory, card catalogue, and classical alphabetic catalog), and the Library's inadequate storage facilities.
\end{abstract}

Keywords: Music Faculty Library, periodicals, structure, content, processing, acquisition policy, storage

\section{The Main Features of the Collection}

The periodicals collection of the Belgrade Faculty of Music Library began to take shape already the year the institution was founded. ${ }^{1}$ This included publi-

\footnotetext{
* Author contact information: romanaribic3@gmail.com

1 The Library of the Faculty of Music in Belgrade was founded in 1937, along with the Faculty (until 1973, Music Academy). It is a higher-educational, specialized type of library and falls under the jurisdiction of its main library, the Svetozar Marković University Library. It is a member of the Library Association of Serbia and the International Association of Music
} 
cations that came out successively, for the most part continually, in volumes or books published periodically (monthly, quarterly, semi-annually, and annually), and bear numerical or chronological shelf marks. The periodicals held by the Library comprise the following: journals, reviews, newspapers, bulletins, annuals, chronicles, essay collections, and editions published by societies, universities, institutes, and academies. The holdings are in print and classified in two sections: Yugoslav periodicals, also comprising Serbian periodicals as a separate subsection, and foreign periodicals. In the stacks, these two collections are not separated. The collection is also classified by frequency of use, comprising archived, seldom used, and current periodicals. In total, it comprises 59 Yugoslav and 74 foreign titles. On the basis of researching the interests of our users in certain topics, we have also included two other types of publications in our collection of current periodicals, both in Serbian (31 titles in total) and other languages (26): discontinued periodicals and periodicals that are still published, but the Library is no longer subscribed to them, having kept already obtained issues in its collection (TABLES 1 and 2: summary of periodicals held)

The current Serbian periodicals collection is updated by means of compulsory depositing, purchases, and donations, while the foreign collection is updated by purchases and donations.

Some Serbian and foreign titles are also available online. ${ }^{2}$

Most of the periodicals are in Serbian, Serbo-Croatian, and English; other languages include Slovene, Macedonian, Russian, Bulgarian, Czech, German, Italian, French, and Dutch.

\section{Types of Journals by Topic}

Our Yugoslav and Serbian collection comprises the following journals, classified by topic: musicology journals (Гудало, Мокрањаи, Музикологија, Музички талас, Нови звук / New Sound, Pro тиsica, Ренесанс, Zvuk); eth-

\footnotetext{
Libraries, and, since 2006, of the COBISS library-information system. It plays an indispensable role in the teaching and academic processes at the Faculty and is the most extensive music library in the Balkans. For more, see Романа Рибић (Romana Ribić), “Библиотека Факултета музичке уметности у Београду" (The Library of the Faculty of Music in Belgrade), Панчевачко читалиште, 2009, 8, 14, 76-80 and "Библиотека Факултета музичке уметности у Београду: најбогатија ризница музичке литературе у земљи” (The Library of the Faculty of Music in Belgrade: The Richest Treasure of Music Literature in the Country), Музика класика: ревија класичне музике, 2013, 4, 12, 35-37.

${ }^{2}$ Нови Звук/New Sound, Музикологија, Мокрањаи (selections), [Панчевачко] Читалиште, Ethnomusicology Forum, The Journal of Musicology, Music Analysis, Music Theory Spectrum, Musical Quarterly, The Musical Times, etc.
} 
Ribic, R.: The Structure, Contents, and Significance of Periodicals Holdings...

nomusicology journals (Folklor, Гусле, Народно стваралаштво), collections/forums (Arti musices: hrvatski muzikološki zbornik, Muzikološki zbornik - Ljubljana, Музичка теорија и анализа - forum, Зборник Матице српске за сиенске уметности и музику), ${ }^{3}$ magazines (Музика класика, Music Marketing, Muzička revija, Orchestra), bulletins (Bilten - Belgrade, Bilten Društva kompozitora Kosova, Bilten Saveza kompozitora Jugoslavije, Bulletin: Muzičke večeri u Donatu, 4[četiri] f[fakulteta], Tpenmaj), informative magazines (Jugoslovenski autor, Jugoslovenski тиzičar, Јужни преглед, Konzertni list, Letopis Matice srpske, Muzičke novine, Muzičke novosti). The collection also comprises publications in pedagogy and psychology (Иноваиије у настави, Настава и васпитање, Психолошка истраживања, Зборник института за педагошка истраживања), literature and the arts (Gradina, Кьижевне новине, Кюижевност, Наслеђе, Nova тіsао, Развитак, Растер, Свеске, TkH - Teorija koja hoda, Treći program, Универзитетска мисао), and IT and library science (Библиотекар, [Панчевачко] Читалиште, Гласник Народне библиотеке Србије, Инфотека, Сусрети библиографа, Високошколске библиотеке).

In terms of Serbian music history, the most important periodicals in our collection also include two eponymous but different periodicals: Музика (1928-29, ed. Miloje Miljević) and Музика (1948-51, ed. Stana Đurić Klajn), as well as Гласник Музичког друштва „Станковић“. 4 The periodicals that have come out without interruption include Мокрањаи, Музикологија, Музички талас, ${ }^{5}$ New Sound, and Зборник Матице српске за сиенске уметности и музику. Also noteworthy are news magazines, started in 2010: the bulletin Tpenmaj of

${ }^{3}$ These essay collections and some of these journals, for the most part of literary significance (Развитак, Свеске Матице српске), and self-marked as music articles (MUZ.ČL) are stacked among monograph publications. See TABLE 1.

${ }^{4}$ An official body of the Yugoslav Choral Union and Stanković Society of Music, eds. Stana Đurić Klajn and Milenko Živković. It was published from 1928 to 1934 and from 1938 to 1941; in 1931, it was renamed Музички гласник. Cf. Александар Васић (Aleksandar Vasić), „Рецепција авангардне музике у међуратном Београду: пример часописа Музика и Гласник Музичког друштва 'Станковић'/ Музички гласник“" (The Reception of Avant-garde Music in Interwar Belgrade: The Example of the Journals Музика and Гласник Музичког друштва “Станковић” / Музички гласник), Зборник Матице српске за сиенске уметности и музику, 2011, 44, 133-151 and "Инострана музика у међуратном Београду: рецепција у Гласнику Музичког друштва 'Станковић' / Музичком гласнику 1928-1941" (Foreign Music in Interwar Belgrade: Its Reception in Гласник Музичког друштва “Станковић” / Музички гласник 1928-1941), Зборник Матице српске за сценске уметности и музику, 2013, 49, 63-75.

${ }^{5}$ Publication was interrupted in 2004 and 2005. 
the Faculty of Music in Belgrade ${ }^{6}$ and Музика Класика, ${ }^{7}$ as the only contemporary Serbian magazine on music.

Our collection of foreign periodicals also includes articles by authors who discuss various views in music aesthetics (Acta Musicologica, Current Musicology, International Review of the Aesthetics and Sociology of Music, Issues in Contemporary Culture and Aesthetics, The Journal of Aesthetics and Art Criticism, Music \& Letters, Musical Quarterly, The Musical Times, Neue Zeitschrift für Musik, Nineteenth-century Music, Perspectives of New Music, Revue de Musicologie, Studia Musicologica). We also cover issues in performance practice (PPR: Performance, Practice, Review, The Strad, Tempo), folklore (Ethnomusicology, Ethnomusicology Forum, Yearbook for Traditional Music), as well as European and non-European contemporary music (Hungarian Music News, Hungarian Music Quarterly, Slowakische Music, La Vie musicale Belge, American Musical Digest, Journal of the American Musicological Society). The collection also includes essay collections on individual figures (The Journal of the Arnold Schoenberg Institute), as well as on pedagogy (American String Teacher, Journal of Research in Singing and Applied Vocal Pedagogy, Maryland Music Educator, Schweizerische Musikpädagogische Blätter).

Also, our foreign collection features bulletins (Bulletin of American Composers Alliance), magazines (The Etude), and information sheets (Gaudeamus Information, Musik-Information). However, some of the publications in this group, published during the latter half of the $20^{\text {th }}$ century, have been discarded due to loss of currency (Bulletin del' UNESCO), while some of them have been discontinued (Nordic Sounds).

As a member of the International Association of Music Libraries (IAML), ${ }^{8}$ the Library regularly receives its bulletin - Fontes artis musicae, which contains mostly conference reports and reports on the Association's activities. ${ }^{9}$ The Library was also subscribed to Notes, ${ }^{10}$ the magazine of the US Music Library Association (MLA), ${ }^{11}$ which offers music bibliographies and reviews of the latest publications in music. The Library was also subscribed to RILM Abstracts of

\footnotetext{
${ }^{6}$ Also available on the Faculty's official webpage: http://www.fmu.bg.ac.rs/fmu/bilten.html (May 9, 2014)

${ }^{7} \mathrm{http}: / /$ www.muzikaklasika.com/

${ }^{8}$ International Association of Music Libraries (http://www.iaml.info/).

${ }^{9}$ The Library received the journal intermittently between 1963 and 1993, and then regularly until 2004.

${ }^{10}$ From 1970 to 1974 and from 1990 to 1992.

${ }^{11}$ Music Library Association (http://www.musiclibraryassoc.org/)
} 
Ribic, R.: The Structure, Contents, and Significance of Periodicals Holdings...

Music Literature ${ }^{12}$ since 2010 , the Library has provided online access to RILM via EBSCO database. ${ }^{13}$

From a historical point of view, the most valuable periodicals in the Library's holdings include the Italian Rivista musicale italiana, founded in 1894 (Turin and Milan), as the oldest magazine in the Library's collection, ${ }^{14}$ as well as the German magazine Die Musik, founded in 1901 (Berlin and Leipzig), ${ }^{15}$ and the oldest Croatian church music journal, Sv. Cecilija (Zagreb), founded in $1877 .{ }^{16}$

\section{Technical Features}

Regarding our collection's technical features, one should note its ability to amend the following data:

- journal title (in most cases, with a similar thematic conception);

- place of publication, possibly with a different publisher;

- International Standard Serial Number (ISSN);

- frequency of publication, and

- continuity.

An especially illustrative example is the Yugoslav journal Звук: ревија за музику, edited by Stana Đurić Klajn. It was published in Belgrade between 1932 and 1935 , when it was temporarily discontinued..$^{17}$ In 1955 , it was revived in Belgrade, ${ }^{18}$ and in 1967 moved to Sarajevo. In 1989-1990, it was based in Zagreb, where it was finally discontinued. ${ }^{19}$ After a three-year break, at the initiative of the Union of Composers' Organizations of Yugoslavia in Belgrade, the publication of the journal was relaunched, to be later (1997) entrusted to the Union's Music Information Centre. In 2008, the publication was assumed by the Musi-

\footnotetext{
${ }^{12}$ The Library received printed issues of RILM in continuity between 1967 and 1983 .

${ }^{13} \mathrm{http}$ ://web.b.ebscohost.com/ehost/search/advanced?sid=1067cba7-929f-43b2-b175- d7af1 f9b0bbf\%40sessionmgr112\&vid=1\&hid=118 (accessed March 9, 2015).

${ }^{14}$ The Library holdings contain the following issues: 4 (1897), 1-3 (1898), 2, 4 (1899), 2 (1900), 1 (1901), 4 (1920), 1-6 (1938), 1-6 (1939), 1-6 (1940), and 1-4 (1953).

${ }^{15}$ The Library holds an incomplete collection, including all issues from the first to the last, published in 1941. In 1943, after a two-year break, the journal was merged with two other German periodicals, Zeitschrift für Musik, Allgemeine Musikzeitung and Neues Musikblatt, into a new journal titled Musik im Kriege.

${ }^{16}$ The Library contains all issues published between 1907 and 1944, and between 1969 and 1973.

17 ISSN 2334-8860.

18 ISSN 0044-555x.

${ }^{19}$ Роксанда Пејовић (Roksanda Pejović), “Четири југословенска Звука” (The Four Yugoslav Zvuks), Нови Звук, 1993, 1, 1, 29-53.
} 
cology Department of the Faculty of Music in Belgrade. Issues Nos. 1-31 were printed bilingually under the bilingual title of Нови Звук: интернационални часопис за музику ${ }^{20}$ and New Sound: International Journal of Music, ${ }^{21}$ and, starting from No. 32, in English only. In 2004, the journal got its official Internet page, which is currently under reconstruction. ${ }^{22}$ Full-text issues are available in the database of the Serbian Citation Index from No. 7 (1996) to No. 31 (2008) in Serbian and from No. 33 (2009) to No. 40 (2012) in English, ${ }^{23}$ and on the journal's web page from No. 24 onwards. ${ }^{24}$

Regarding foreign periodicals, one should note the international journal for the study of traditional music and dance Yearbook for Traditional Music (Canberra, Australia: ICTM) ${ }^{25}$ Since its launch in 1949, the journal has come out under various titles and with various ISSNs: Journal of the International Folk Music Council (Vols. 1-20, 1949-1968), ${ }^{26}$ Yearbook of the International Folk Music Council (Vols. 1-12, 1969-1980), ${ }^{27}$ and since 1981 under its current title, Yearbook for Traditional Music (Vols. 13-). ${ }^{28}$ The journal was planned to relocate its headquarters to Ljubljana from July 2011 to July 2015.

There are also examples of changes of frequency, such as that of The Musical Times, which was launched in 1844 (at 12 issues a year, then, from 1998, seven issues a year, and then, since 1999, quarterly). ${ }^{29}$ Another interesting example is that of the first Serbian music periodical, Гудало, launched in 1886/87, whereupon ten issues came out. Then, there was a 100-year break, before the journal was revived on the occasion of its centenary in 1986 and three issues were published: No. 11 (Vol. 101, 1986), No. 12 (Vol. 111, 1996), and No. 13 (Vol. 127, 2012), when it was discontinued again. ${ }^{30}$

\footnotetext{
${ }^{20}$ ISSN 0354-4362 (print).

${ }^{21}$ ISSN 0354-818x (print).

${ }^{22} \mathrm{http}$ //www.newsound.org.rs/.

${ }^{23}$ No. 32 was omitted from both versions.

${ }^{24}$ ISSN 1821-3782 (online).

${ }^{25}$ The International Council for Traditional Music is a non-governmental organization for the study, preservation, and presentation of the world's musical heritage.

${ }^{26}$ ISSN 09507922.

${ }^{27}$ ISSN 03166082.

${ }^{28}$ ISSN 0740-1558 (print); ISSN 2304-3857 (online).

${ }^{29}$ The Library holds an incomplete collection of issues from 1938-39 to 2004 (missing issues between 1999 and 2002); the Library ended its subscription in 2007.

${ }^{30}$ Гудало: часопис за унапређење глазбе/музике, [Velika] Kikinda, [Академско] друштво за неговање музике „Гусле“, eds. Milan Petrović (1886), Milovan Miškov (1996), Selena Rakočević (2012), ISSN 2334-6965. The Library holds issues Nos. 11-13.
} 
Ribic, R.: The Structure, Contents, and Significance of Periodicals Holdings...

\section{A Description of the Structure of the Periodicals in the Collection, their Categorization, and the Valorization of Music and Other Scholarly Journals in the Holdings of the Faculty of Music Library}

The periodicals in the holdings of the Faculty of Music Library that are classified as scholarly ${ }^{31}$ must feature the following (in each issue): an editorial introduction, an original scholarly paper, a summary paper, an expert paper, a brief report, scholarly critique/debate, and reviews (of monographs, articles, audio and video editions, and web pages). Periodicals outside of this category may also contain scholarly articles (in the form of essays and studies, e.g. Народно стваралаштво: фолклор), but for the most part these periodicals contain reviews of books and new works, reports on events - competitions, festivals, portraits of musicians, jubilees, obituaries, polemics (Zvuk, Pro musica), and reports (the activities of the Artistic-academic Council in Билтен Универзитета уметности у Београду).

The Serbian scholarly periodicals that the Library receives regularly or whose issues it received as compulsory depository issues or via subscription include periodicals with diverse topics: music (Нови Звук/New Sound, Мокрањаи, Музикологија, Музички талас), pedagogy and psychology (Зборник Института за педагошка истраживања, Психолошка истраживања), literature and the arts (Наслеђе, Свеске, Развитак, Трећи програм, 32 Зборник Матиче српске за сиенске уметности и музику), and IT library science (Библиотекар, [Панчевачко] Читалиште, Гласник Народне библиотеке Србије). According to the 2013 ranking list of the Ministry of Education, Science, and Technological Development of the Republic of Serbia, ${ }^{33}$ modelled on the publications of the international Institute for Scientific Information ${ }^{34}$ and the annual informa-

\footnotetext{
${ }^{31}$ A scholarly journal is "a periodical publication dedicated to scholarly research, published by a reputable publisher, a scholarly society, or a scholarly institution from Serbia or abroad, which publishes works equipped with a scholarly apparatus and reviewed by competent experts with appropriate academic titles"; Ministry of Education, Science, and Technological Development of the Republic of Serbia, Guidelines on the Procedure and Way of Valorizing and Quantifying Scholars' Achievements in Academic Research, Belgrade, Official Gazette of the Republic of Serbia, No. 38/08, http://www.mpn.gov.rs/images/content/nauka/pravna akta/PRAVILNIK_o_zvanjima.pdf (accessed May 18, 2014).

32 The Library has copies of all issues of Развитак up to 1998, and Свеске and Трећи програм up to 2006.

33 Ministry of Education, Science, and Technological Development, "Категоризација часописа у 2013." (Categorization of Periodicals for 2013), http://www.mpn.gov.rs/nauka/ razvoj-naucnih-kadrova/53-kategorizacija-casopisa/773-kategorizacija-naucnih-casopisa2013 (accessed Aug. 19, 2014.)

${ }^{34}$ According to the Arts \& Humanities Citation Index and the Social Science Citation Index.
} 
tion sheet Journal Citation Reports ${ }^{\circledR}$ (JCR) of the Web of Science ${ }^{\circledR}$ (WOS) database, ${ }^{35}$ to which the Serbian academic community is subscribed, the Serbian periodicals listed above belong in the following categories: M 24, M51, M 53, and PK 53.

The national journals of international significance (M 24) include Нови Звук/New Sound, Музикологија, and Зборник Института за педагошка истраживања. The leading journals of national significance (M 51) include Психолошка истраживања, Трећи програм, and Зборник Матище српске за сиенске уметности и музику. The category of periodicals of national significance (M 52) comprises only one journal, [Панчевачко] Читалиште, while that of periodicals whose impact in their discipline is under $50 \%$, that is, periodicals that are neither international nor among the top 50\% in their rank (M 53), includes the following: Мокрағаи, Музички талас (РК 53), ${ }^{36}$ Наслеђе, Свеске, Развитак, Библиотекар, and Гласник Народне библиотеке Србије. The impact of domestic journals is determined by means of bibliometric analysis, impact factor, and preliminary categorization (PK). ${ }^{37}$ Impact factor is a bibliometric indicator that quantifies a journal's impact in its field, which is calculated by dividing the number of citations of articles published a given journal during the last two years with the number of articles published in that journal over the same period. ${ }^{38}$ The five-year impact factor is calculated in the same way, except that the observed period is five rather than two years. Unfortunately, because the publishing house CEON (Centar za obrazovanje i evaluaciju u nauci) switched to self-funding in 2015, the music periodicals listed above, with the exception of New Sound, ${ }^{39}$ are not listed in the database of the Serbian Citation Index. ${ }^{40}$

Музикологија and New Sound are the only Serbian music periodicals that are indexed in the DOI (Digital Object Identifier) system of cross-referencing

\footnotetext{
${ }^{35} \mathrm{http}: / /$ thomsonreuters.com/journal-citation-reports/.

${ }^{36} \mathrm{PK}=$ preliminarna kategorija (preliminary category).

${ }^{37}$ CEON. Centar za obrazovanje i evaluaciju u nauci. "Preliminarna kategorija" (Preliminary Category). http://scindeks-bic.ceon.rs/help/help.html (accessed Mar. 25, 2015).

${ }^{38}$ For instance, the 2013 impact factor of a journal is calculated by adding the number of citations from 2012 and 2011 and dividing it by the total number of papers published in that journal during those two years. http://kobson.nb.rs/vrednovanje/vrednovanje/prica_o_if.129. html (accessed Feb. 28, 2015).

${ }^{39}$ The five-year impact factor of New Sound is 0.033. See http://scindeks.ceon.rs/journaldetails.aspx?issn=0354-818 (accessed Mar. 26, 2015).

40 http://www.ceon.rs/index.php/sr/88-vesti/328-scindeks-menja-oblik-obim-i-nacin-finansi ranja-saopstenje-ceon-a (accessed Mar. 7, 2015).
} 
Ribic, R.: The Structure, Contents, and Significance of Periodicals Holdings...

via the Scientific Information Centre of the National Library of Serbia. ${ }^{41}$ New Sound is also registered in the ERIH (European Reference Index for the Humanities) database, ${ }^{42}$ and searching for articles is also available through the EBSCO aggregator. ${ }^{43}$ The articles published in all issues of Музикологија so far are also available in full text in the regional database Комуникација. ${ }^{44}$

The ranking of the foreign current periodicals that the Library obtains through subscription and donations is monitored via the SJR (SCImago Journal \& Country Rank) portal, which enables the bibliometric monitoring of access indicators and analysis of scholarly journals in the SCOPUS database..$^{45}$ We have presented several different parameters whereby the impact of journals in their field is calculated: the SJR indicator, ${ }^{46} \mathrm{H}$-index, ${ }^{47}$ the number of all documents over the last three years, the total number of citations and their ratio to all documents in the selected period, etc. We have arranged the foreign periodicals in our collection according to their H-index values in 2013: Neue Zeitschrift für Musik =1, Fontes artis musicae $=2$, Revue de musicologie = 2, Studia musicologica Academiae scientarium hungaricae $=2$, Acta musicologica $=3$, Yearbook for Traditional

${ }^{41} \mathrm{http}: / /$ www.doiserbia.nb.rs/.

42 DBH, "ERIH PLUS", NSD, https://dbh.nsd.uib.no/publiseringskanaler/erihplus/info?id= 482229 (accessed May 20, 2014).

43 "Aggregator refers to a web site or computer software that aggregates a specific type of information from multiple online sources." http://en.wikipedia.org/wiki/Aggregator (accessed May 27, 2015). Articles from New Sound are available in the EBSCO (Information Services) database at http://web.a.ebscohost.com.proxy.kobson.nb.rs:2048/ehost/ resultsadvanced? sid=f324aab3-88a8-4b24-a81d-fa55992ce9ce\%40sessionmgr4003\&vid $=4$ $\&$ hid $=4206 \&$ bquery $=\mathrm{TI}+$ new + sound + magazine $\&$ bdata $=$ JmRiPWFwaCZkYj1idWgmZGI9 ZXJpYyZkYj1mNWgmZGI9Y211ZG0mdHlwZT0xJnNpdGU9ZWhvc3QtbG12ZQ\%3d\%3 d (accessed May 27, 2015).

$44 \mathrm{http} / /$ www.komunikacija.org.rs/komunikacija/casopisi/muzikologija/index_html?stdlang =ser_cyr; http://www.komunikacija.org.rs/komunikacija/casopisi/muzikologija/index_html? stdlang=ser_lat

${ }^{45}$ SCImago Journal \& Country Rank (SJR), "Journal Rankings", http:/www.scimagojr. com/journalrank.php?area $=1200 \&$ category $=1210 \&$ country $=$ all \&year $=2013 \&$ order $=$ sjr $\& \mathrm{mi}$ $\mathrm{n}=0$ \&min_type $=\mathrm{cd}$ (accessed Feb. 28, 2015).

${ }^{46}$ The SJR indicator refers to the average number of citations in documents printed over the last three years.

47 The H-index was named after the Argentine-American physicist Jorge E. Hirsch (1953). It is accepted by the scientific community in general due to its simple and practical use. It is used to measure the individual performance of authors, as well as journals in general. It is a substitute for the impact factor. See http://kobson.nb.rs/vrednovanje/vrednovanje/h_-_index.120.html (accessed May 20, 2014); http://www.scimagojr.com/help.php (accessed Mar. 24, 2015). 
Music $=4$, Ethnomusicology $=7$, Journal of Music Theory $=7$, The Journal of Musicology = 8, Nineteenth-century Music = 8, Music Analysis = 9, Music Theory Spectrum $=11$, Journal of the American Musicological Society $=11 .{ }^{48}$ (TABLE 3: H-index)

In the example above, the H-index values refer to the number of documents with the greatest number of citations in other journals. A journal with a large number of citations is considered highly influential in its field. The advantage of this index is that, unlike the impact factor, it also takes into account conference papers, as well as articles in journals that are not on the ISI list. A deficiency of the $\mathrm{H}$-index is that it does not indicate the number of times a given article has been cited. ${ }^{49}$

\section{Processing, Acquisitions, Storing}

\subsection{Inventory Book, Card Catalogue, Catalogue}

The Library keeps a record of its periodicals collection in its inventory book, files, and paper catalogue..$^{50}$

The Faculty Library inventory book contains the following data for each item: inventory number, date of inventory, short description (title and place of publication), mode of acquisition (in the case of purchase - receipt number and reference number; in the case of donation - reference number), price, and additional notes. Every item is inventoried separately. ${ }^{51}$

The card catalogue is divided in two sections: current and archived periodicals. In the current section, Serbian publications are catalogued separately from foreign publications, while in the archived section, all publications are catalogued together. The cards are arranged in Latin alphabetical order, because the Library's official script is Latin. (IMAGE 1: A journal card)

However, the Library's paper catalogue contains only selected titles, mostly from current periodicals. This is due to the size of the periodicals collection,

48 Downloading full-text articles from these journals is available to JSTOR users through the Consortium of Libraries for Joint Acquisitions (KoBSON).

${ }^{49}$ Cf. Anne-Wil Harzing, Ron van der Wal, “A Google Scholar H-Index for Journals: A Better Metric to Measure Journal Impact in Economics \& Business?", Journal of the American Society for Information Science and Technology, 2009, 60, 1, 41-46; http://www.harzing. com/papers.htm\#gshindex (accessed Mar. 24, 2015).

${ }^{50}$ Automatic processing has yet to be introduced.

${ }^{51}$ According to the "Guidelines on the Inventory, Processing, Revision, and Discarding of Library and IT Materials and Sources, as well as Keeping Records of Library and IT Materials and Sources", Belgrade, Official Gazette of the Republic of Serbia, No. 47/13. 
Ribic, R.: The Structure, Contents, and Significance of Periodicals Holdings...

which was never, since the very beginning, properly catalogued, as well as due to the fact that only one librarian is assigned the task of processing it. Adapted to the users' needs, the catalogue was formed by combining the basic, alphabet catalogue, with a topical, analytical catalogue. Namely, the titles of the journals, as the main entries, are earmarked, divided into Serbian and foreign, and arranged in alphabetical order. Each individual entry contains a series of analytical items on the article's author, in an individual subentry. The analyzed articles are mostly studies, expert works, and reviews, while reviews of monograph publications and non-printed materials, as well as conference and congress reports are for the most part omitted. The catalogue shows basic analytical elements: title of article, authorship data, year, volume, and issue of journal, and number of pages, but without UDK $^{52}$ and ISSN numbers. ${ }^{53}$

\subsection{Updating the Holdings; the Acquisition Policy and Storing}

Since the very beginning of the periodicals collection, the Library has updated its holdings in three ways: with purchases (as the primary mode of planned acquisition), donations, and compulsory depositing. The Library does not engage in exchanging journals. Current Serbian periodicals are typically acquired by means of compulsory depositing and donations, and, less often, by purchase. The acquisition of foreign journals is entrusted to a single supplier. With very limited financial means, the Library updates its foreign periodicals collection on the basis of desiderata from the Faculty's teaching staff.

Of course, it was necessary to ensure that the existing holdings be physically protected and cleansed of redundant materials. The last (incomplete) revision of the periodicals collection was conducted in $2012 .{ }^{54}$ At that time, damaged and incomplete publications, duplicates, and obsolete reference periodicals (teach-

\footnotetext{
${ }^{52}$ Univerzalna decimalna klasifikacija - universal decimal classification.

${ }^{53}$ Cf. Bojana Vukotić, “Новине у стандарду за обраду серијских публикација” (Innovations in the Standards for Processing Serial Publications), Гласник Народне библиотеке Србије, 2005, 7, 1, 73-88; IFLA, Guidelines for the Application of the ISBDs to the Description of Component Parts, Washington D.C., Cataloging Directorate, Library of Congress, 2003, http://www.ifla.org/files/assets/cataloguing/isbd/component-parts.pdf (accessed Aug. 26, 2014).

${ }^{54}$ On the basis of Article 53, Paragraph 1, Point 4 of the Higher Education Act, Belgrade, Службени гласник Републике Србије (Official Gazette of the Republic of Serbia), No. 76/05 and Article 15, Paragraph 1, Point 4 of the Statute of the Faculty of Music in Belgrade, adopted by the ruling of the Faculty's Academic-artistic-teaching Council No. 01-969/12 of April 27, 2012, according to Article 35 of "Guidelines on the Inventory, Processing, Revision, and Discarding ...", op. cit.
} 
ing reports, guidelines, and the like) were discarded.

An adequate storing space, in line with international standards, has yet to be provided. The gallery space where the periodicals are stacked is much too small for such a large collection. Since the collection is not fully catalogued, it is available on open access. Unfortunately, in such inadequate conditions of work, users' access to the collection is much harder than it ought to be.

\section{Conclusion}

The periodicals in the holdings of the Belgrade Faculty of Music Library constitute an important collection, both in terms of their scholarly, pedagogical, cultural, and historical value, as well as their sheer number and the size of the collection. Their impact on higher-education teaching and the productivity and quality of research conducted at the Faculty is manifested in the dissemination of current information in scholarship, music, and the arts. It is well-known that music literature in the form of monograph publications often contains data that is no longer topical or justified and, as such, may not always be reliable. By contrast, periodicals offer not only historical testimonies about the development of musical culture over the decades, but also a wealth of useful current information and different guidelines for the development of the discipline and its improvement. Unfortunately, the librarians of the Faculty of Music receive little feedback from its users, due to their insufficient familiarity with the available sources of "fresh" data. In addition, it is also vital to develop an awareness of the advantages of including electronic sources in the Faculty's research and teaching processes. Therefore, by automating its periodicals collection as well, and by providing online subscription to certain foreign periodicals, the Library could fully realize its basic tasks and objectives. 
Ribic, R.: The Structure, Contents, and Significance of Periodicals Holdings...

\section{TABLE 1}

Summary of Yugoslav and Serbian periodicals in the holdings of the Belgrade Faculty of Music Library*

\begin{tabular}{|c|c|}
\hline SECTION & TITLE OF JOURNAL \\
\hline $\begin{array}{l}\text { Current and less } \\
\text { frequently used } \\
\text { Serbian periodicals }\end{array}$ & 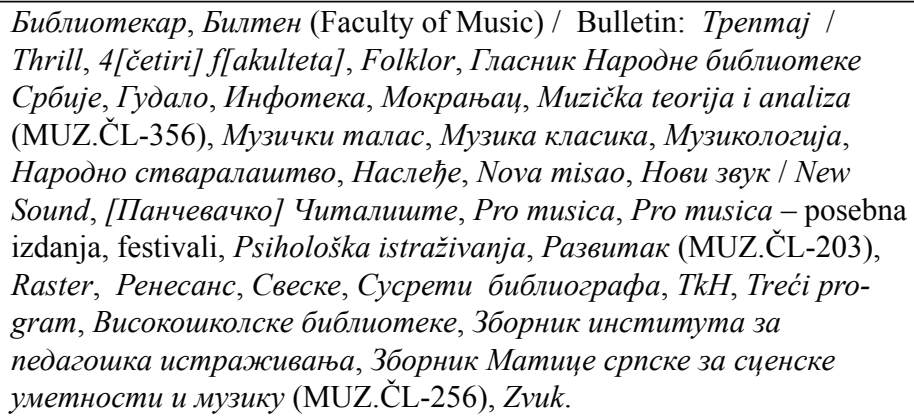 \\
\hline $\begin{array}{l}\text { Archive: Yugoslav } \\
\text { and Serbian } \\
\text { Periodicals }\end{array}$ & 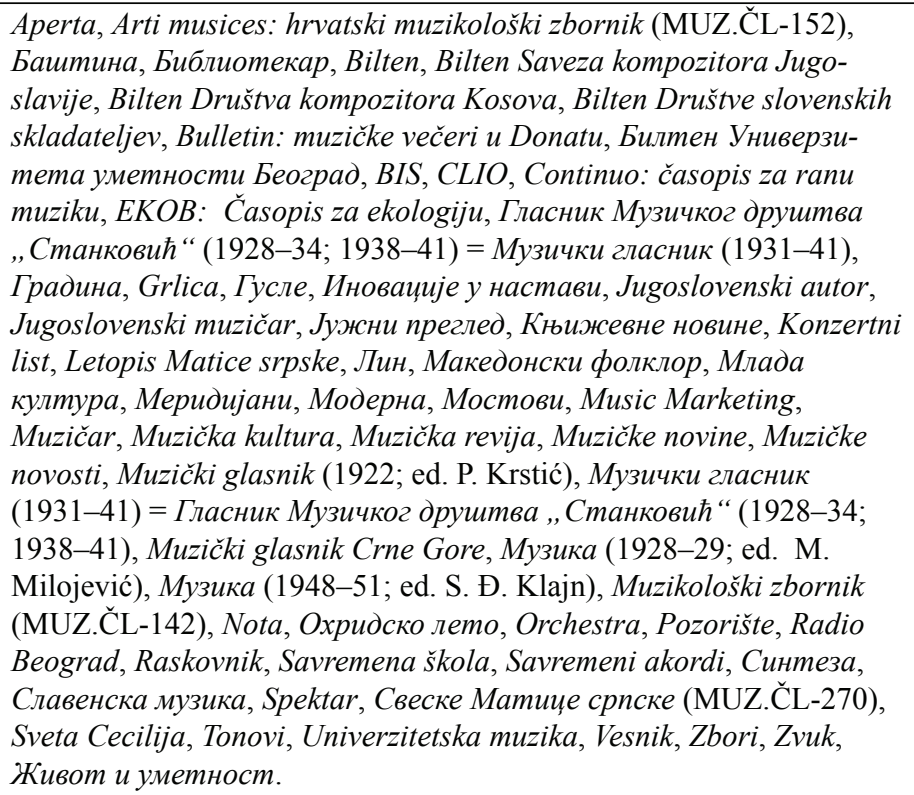 \\
\hline
\end{tabular}

* The journals appear in Latin alphabetic order because the Library's official script is Latin. 


\section{TABLE 2}

\begin{tabular}{|c|c|}
\hline \multicolumn{2}{|c|}{ Summary of Foreign Periodicals in the Holdings of Belgrade Faculty of Music Library } \\
\hline SECTION & TITLE OF JOURNAL \\
\hline $\begin{array}{l}\text { Current and } \\
\text { seldom used } \\
\text { foreign } \\
\text { periodicals }\end{array}$ & $\begin{array}{l}\text { Acta musicologica, Dance Research, Dutch Journal of Music Theory, Eth- } \\
\text { nomusicology, SEM Newsletter, Ethnomusicology Forum, Finnish Music } \\
\text { Quarterly, Fontes artis musicae, Glasbeno-pedagoški zbornik, Journal of } \\
\text { the American Musicological Society, AMS Newsletter, The Journal of Mu- } \\
\text { sicology, Journal of Music Theory, Music Analysis, Music \& Letters, } \\
\text { Music in Art, Music Theory Spectrum, Musical Quarterly, The Musical } \\
\text { Times, Muzika, Neue Zeitschrift für Musik, Nineteenth-century Music, Ös- } \\
\text { tereichische Musikzeitschrift, Perspectives of New Music, Revue de musi- } \\
\text { cologie, Studia musicologica, Theoria, Yearbook for Traditional Music }\end{array}$ \\
\hline $\begin{array}{l}\text { Archive: } \\
\text { foreign periodi- } \\
\text { cals }\end{array}$ & 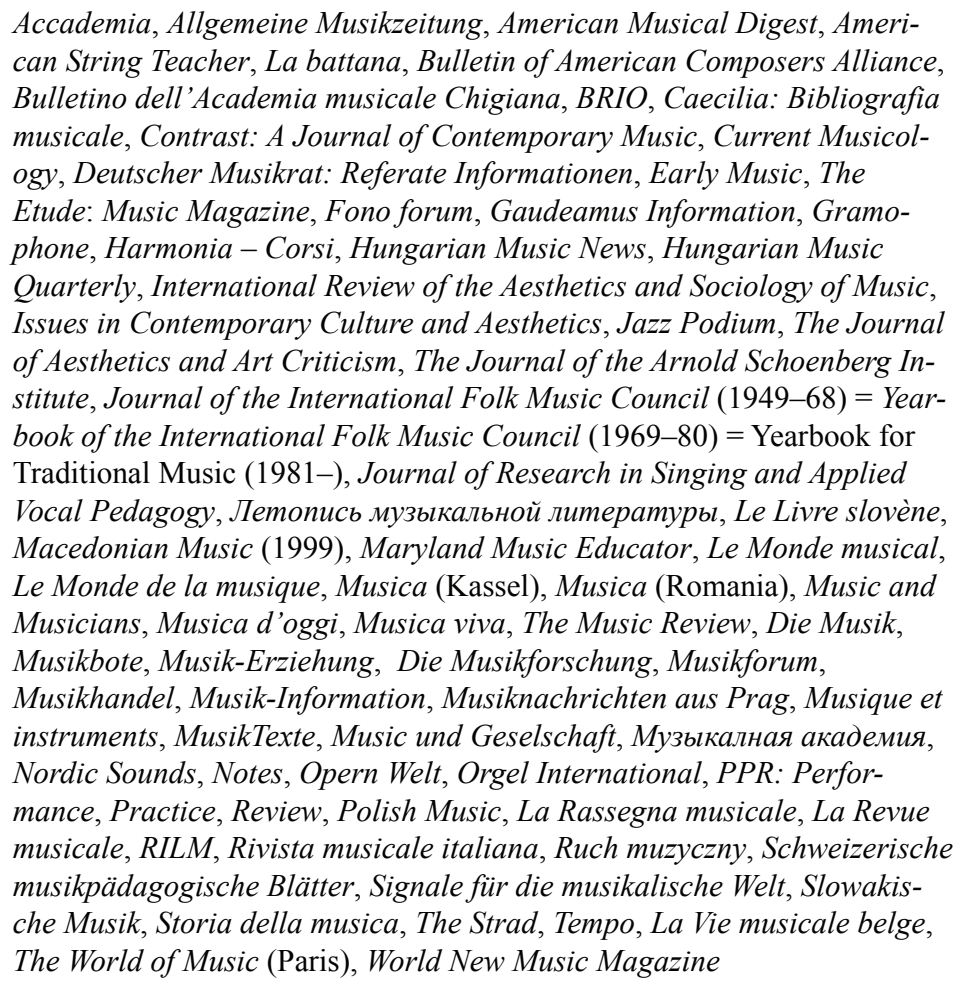 \\
\hline
\end{tabular}


Ribic, R.: The Structure, Contents, and Significance of Periodicals Holdings...

TABLE 3 - 2013 H-index

\begin{tabular}{|c|c|c|c|c|c|}
\hline $\begin{array}{l}\text { TITLE OF J } \\
\text { OURNAL }\end{array}$ & SJR & $\begin{array}{l}\text { H-in- } \\
\text { dex }\end{array}$ & $\begin{array}{l}\text { Total number } \\
\text { of documents }\end{array}$ & $\begin{array}{l}\text { Total number } \\
\text { of references }\end{array}$ & $\begin{array}{l}\text { Total number } \\
\text { of reference / } \\
\text { Total number } \\
\text { of documents }\end{array}$ \\
\hline $\begin{array}{l}\text { Neue Zeitschrift für } \\
\text { Musik }\end{array}$ & 0.100 & 1 & 135 & 413 & 3.06 \\
\hline Fontes artis musicae & 0.120 & 2 & 0 & 0 & 0.00 \\
\hline $\begin{array}{l}\text { Revue de musicolo- } \\
\text { gie }\end{array}$ & 0.101 & 2 & 12 & 35 & 2.92 \\
\hline $\begin{array}{l}\text { Studia musicologica } \\
\text { Academiae scientar- } \\
\text { ium hungaricae }\end{array}$ & 0.112 & 2 & 6 & 0 & 0.00 \\
\hline Acta musicologica & 0.105 & 3 & 0 & 0 & 0.00 \\
\hline $\begin{array}{l}\text { Yearbook for Tradi- } \\
\text { tional Music }\end{array}$ & 0.168 & 4 & 0 & 0 & 0.00 \\
\hline Ethnomusicology & 0.183 & 7 & 19 & 743 & 39.11 \\
\hline $\begin{array}{l}\text { Journal of Music } \\
\text { Theory }\end{array}$ & 0.324 & 7 & 7 & 425 & 60.71 \\
\hline $\begin{array}{l}\text { The Journal of Musi- } \\
\text { cology }\end{array}$ & 0.208 & 8 & 16 & 1.108 & 69.25 \\
\hline $\begin{array}{l}\text { Nineteenth-century } \\
\text { Music }\end{array}$ & 0.267 & 8 & 9 & 662 & 73.56 \\
\hline Music Analysis & 0.180 & 9 & 12 & 790 & 65.83 \\
\hline $\begin{array}{l}\text { Music Theory Spec- } \\
\text { trum }\end{array}$ & 0.196 & 11 & 11 & 549 & 49.91 \\
\hline $\begin{array}{l}\text { Journal of the Ameri- } \\
\text { can Musicological } \\
\text { Society }\end{array}$ & 0.361 & 11 & 26 & 1.968 & 75.69 \\
\hline
\end{tabular}

